\title{
Filosofická praxe v České republice
}

\author{
Lukáš Mareš \\ Teologická fakulta \\ Jihočeská univerzita \\ v Českých Budějovicích \\ Branišovská 1645/31, 37005 \\ České Budějovice \\ mares103@tf.jcu.cz
}

\author{
Václav Peltan \\ Teologická fakulta \\ Jihočeská univerzita \\ $v$ Českých Budějovicích \\ Branišovská 1645/31, 37005 \\ České Budějovice \\ peltav00@tf.jcu.cz
}

\author{
Eliška Havlová \\ Pedagogická fakulta \\ Jihočeská univerzita v Českých Budějovicích \\ Branišovská 1645/31, 37005 České Budějovice \\ havlova.eli@gmail.com
}

Pojem filosofie nabyl v průběhu historie řadu podob a významů. Kromě tradičního teoretického zaměření se lze setkat s př́stupem, který vyzdvihuje praktický dopad filosofování na život člověka. Příspěvek představuje koncept filosofické praxe a reflektuje její současný stav na území České republiky. Autoři vymezují filosofickou praxi jako disciplínu filosofie a načrtávají její možné dělení na dílčí oblasti. Nastíněny jsou její historické kořeny, které autoři identifikují v antickém Řecku. Dále se věnují systematickému představení doposud sepsaných materiálů k filosofické praxi a přehledu její realizace na území České republiky. Detailní pozornost věnují autoři popisu tří jejích oblastí, mezi které patří filosofie pro děti ( $\mathrm{P} 4 \mathrm{C})$, filosofický workshop a filosofická konzultace. Kromě teoretického vymezení reflektují rovněž své vlastní postupy v uvedených oblastech. Text čerpá především ze zahraniční odborné literatury, konkrétně z textů a dalších materiálů filosofických praktikantů. Jeho cílem je představit českému čtenáři doposud podrobněji neřešený koncept filosofické praxe, a připravit tak pole pro možnou akademickou diskusi.

Kličová slova: filosofická praxe, dialog, filosofie pro děti, P4C, filosofický workshop, filosofická konzultace 


\section{1. Úvod - Vymezení filosofické praxe}

Co je to filosofická praxe? Zmíněné sousloví se v odborné literatuře objevuje poměrně krátce a nutno dodat, že vzbuzuje rozpaky. Paradoxní je na tom fakt, že se často pojí neshody s tímto souslovím i uvnitř samotné filosofické praxe. Text představuje filosofickou praxi jako odvětví či disciplínu filosofie, která se v mnohém dotýká rovněž pedagogiky a psychologie. Zařazení do oblasti filosofie zdůvodňujeme především užívanými metodami, cíli, rovinami a odkazy na filosofickou tradici (zejména důrazem na texty a myšlenky autorů-filosofü). Velká část kritiky zaznívá nejen z úst psychoterapeutů, ale i z řad samotných filosofü. Nejprve je ale zapotřebí si dostatečně vyjasnit všechny jednotlivé podoblasti filosofické praxe, do kterých spadá mnoho prŕbuzných aktivit, technik a inspirací. Pokusíme se navrhnout systematické rozlišení doposud nevyjasněné terminologie, ukázat historické kořeny filosofické praxe, představit současný stav bádání a realizace v českém prostředí a rovněž seznámit čtenáře se třemi základními oblastmi, kterými jsou filosofie pro děti ( $\mathrm{P} 4 \mathrm{C})$, filosofický workshop a filosofická konzultace.

Pojem „filosofická praxe“ chápeme jako název odvětví filosofie, ${ }^{1}$ které se od 80. let 20. stoletín začíná postupně etablovat a získávat celosvětový vliv. Zároveň se také podle nás jedná o nadřazený pojem, který zaštituje veškeré formy setkávání filosofických praktikantů s účastníky různých věkových skupin (viz obr. 1). Filosofická praxe, jak už je z jejího názvu patrné, se snaží filosofii přenést do praxe. Tento obrat lze ilustrovat takto: Jako by sami filosofové zapomínali na praktické důsledky svých činů a myšlenek ve světě a chtěli být „zase“ nápomocni lidem k lepšímu chápání sebe samých a světa kolem nich tak, jako tomu bylo v antické filosofii (s odkazem na její interpretaci podle P. Hadota ${ }^{3}$ ). Tento pedagogicko-psychologický motiv neustále vystupuje $\mathrm{v}$ historii filosofie

\footnotetext{
1 Vedle filosofie teoretické (metafyzika), praktické (etika, ale i např. filosofie výchovy), aplikované a experimentální (systematické experimenty, které mají za cíl poskytnout hlubší vhled do toho, jak lidé běžně přemýšlejí o problémech s filosofickým kontextem).

2 Začátek filosofické praxe jakožto hnutí se obvykle pojí s osobou německého filosofa G. Achenbacha (narozen 1947), který si v roce 1982 založil v Německu Gesellschaft für Philosophische Praxis. Viz Šulavík (2001).

3 P. Hadot (1922-2010) byl francouzský filosof, který se věnoval neoplatonismu a historii filosofie. Slavný se stal kvůli své interpretaci antické filosofie jako způsobu života. Viz Hadot (1995a, 1995b, 2012).
} 
jako klíčový pro ni samou (J. Patočka, J. Pešková ad.). Jakožto filosofové ovšem musíme mít neustále na paměti jedno z největších úskalí tohoto obratu, který popsal Platón v Ústavě (podobenství o jeskyni), ${ }^{4}$ totiž úskalí neúspěchu a nepochopení filosofa. Na konci 20. století se objevuje hnutí a myslitelé, kteří chtějí dělat filosofii jinak, prakticky a s přesahem k lidem (nefilosofům). Problémem může být nepochopení, ale i nesystematičnost, neprofesionalita a nízká odbornost filosofických praktikantů ${ }^{5}$.

Naše chápání filosofické praxe bychom mohli načrtnout takto:

\section{Filosofická praxe}

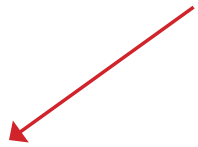

Individuální rovina

Filosofické konzultace

Filosofické poradenství

Filosofický koučink

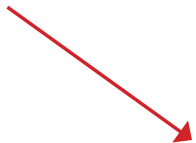

Skupinová rovina

Filosofické workshopy

Filosofie pro děti (P4C)

Obr. 1.

Filosofická praxe se tedy dělí na dvě základní skupiny. Na individuální rovině se dělí na filosofické konzultace, filosofické poradenství a filosofický koučink. Na skupinové rovině se dělí na filosofické workshopy a filosofii pro děti. Práce se skupinou v rámci filosofické praxe se většinou děje právě ve výše zmíněných rovinách, které je dle nás důležité rozlišovat. Pokud filosofický praktikant pracuje s dětmi, je velmi pravděpodobné, že jeho aktivity budou velmi blízké konceptu filosofie pro děti. Pokud pracuje $\mathrm{s}$ dospívajícími či dospělými lidmi, jedná se o filosofický workshop. Na individuální rovině pak rozlišujeme v zásadě mezi konzultací a poradenstvím, a to podle míry filosofického obsahu, používaných nástrojů a blízkosti $\mathrm{k}$ oblasti psychologie. Poradenství chápeme jako oblast patřící spíše do oblasti psychologie, zatímco konzultace svou povahou, formami a obsahem splňuje nároky svébytné

4 Viz Platónova Ústava, Platón (2003, 514b-541b).

5 Tímto pojmem označujeme člověka, který se věnuje jedné či více oblastem filosofické praxe. 
filosofické oblasti. Filosofický koučink je možné vymezit jako techniku práce na rozvoji myšlenkových dovedností a postojů, a to při využití textů či různých cvičení. ${ }^{6} \mathrm{~V}$ současnosti představuje spíše marginální oblast filosofické praxe, a z tohoto důvodu mu v příspěvku nevěnujeme bližší pozornost. $\mathrm{V}$ textu představujeme tři oblasti filosofické praxe, kterým se aktivně věnujeme, považujeme je za filosofické a již etablované.

\section{Historické kořeny filosofické praxe}

Kořeny filosofické praxe nacházíme v antickém Řecku, které bývá zároveň označováno za kolébku filosofie jako takové. Již u předsókratovských myslitelů (napřr. Démokritos) se lze setkat $\mathrm{s}$ rozpracováním etiky a otázkami týkajícími se vedení dobrého života, avšak dochované prameny jsou spíše sporadické. Od doby Sókrata, Platóna a následně Aristotela (5. -4. stol. př. n. 1.) do popředí výrazněji vystupuje důraz na praktický dopad filosofování na život člověka a starání se o duševní život. Uvedené období je proto možné označit za počátek psychologie. Jak uvádí M. Nakonečný, „Filosofické úvahy o duševním životě člověka a o duši a také zkoumání duševního života sebepozorováním a pozorováním druhých lidí ... nacházíme již u starých řeckých filosofů." "7

Pojetí antické filosofie jako životní cesty či osobního hledání a sebetransformace prezentuje P. Hadot či J. M. Cooper. Hadot uvádí, že na počátku filosofování stojí přinejmenším od dob Sókratových otázka volby způsobu života. Filosofický diskurz ${ }^{8}$ začíná u existenciální volby, je vázán na konkrétní školu myšlení a podporuje ji. Filosofická škola znamená právě toto rozhodnutí, které od jedince požaduje zásadní životní změnu, bytostnou transformaci a je v posledku vyjádřením touhy pobývat ve světě určitým způsobem. ${ }^{9}$ Filosofických škol, a tedy i diskurzů, bylo v antice veliké množství, nicméně společným prvkem

6 Pro více informací viz stránku filosofických praktikantů O. Brenifiera a J. Lecoqa: Lecoq, J. (2019a): „Philosophical coaching.“ In Dialogon [Online] Paris, C) 2019 [cit. 4. 4. 2020]. Dostupné z: http://dialogon-en.ugal.com/philosophical-coaching.

7 Viz Nakonečný (2015, s. 14).

8 Hadot tímto pojmem myslí diskurzivní uvažování ve filosofickém smyslu, vyjádřené formou psanou či ústní.

9 Viz Hadot (1995b, česky 2017 s. 15-17). 
byla dle Hadota snaha vést zdařilý život a dosahovat životní moudrosti. ${ }^{10}$ Toho bylo dosahováno nejen teoretickým zkoumáním reality (Aristotelés), získáváním vědění o světě a sobě samém (Sókratés, Platón), ale $\mathrm{v}$ helénistickém období i praktickými návody na žití a duchovními cvičeními ${ }^{11}$ (např. epikureismus, stoicismus či kynismus).

Jednou z nejinspirativnějších postav pro filosofickou praxi je Sókratés. Jeho metoda dialogického zkoumání (exetazein) ${ }^{12}$, kterou uplatňoval při rozhovorech s athénskými občany, spočívala ve zkoumání názorů druhých, v odkrývání složitosti problémů a v hledání správného uchopení pojmů (hledání odpovědí na otázku „Co je...?"). ${ }^{13}$ Sókratés usvědčoval své spoluobčany z nevědomosti o záležitostech, o kterých původně tvrdili, že je znají (metoda elenchos). ${ }^{14}$ Rovněž se je ovšem pomocí otázek snažil přimět k „porodu“ myšlenek a určitému „zvědomění“ jejich přesvědčení tak, aby bylo zřejmé a dalo se s ním v rámci filosofického rozhovoru následně pracovat (maieutická metoda). ${ }^{15}$ Sókratés tak pomocí otázek vedl lidi k tomu, aby zkoumali sebe sama, poznávali podstatu věcí, starali se o vlastní duši, kultivovali se jako osobnosti a žili ctnostně. V Apologii dává Platón do úst Sókratovi výrok „,... život bez zkoušení není člověku hoden žití..."16 Právě důrazem na zkoumání sebe sama a vlastního života společně s důrazem na vedení zdařilého života představuje Sókratés významný inspirační zdroj pro oblast filosofické praxe.

10 Filosof v období antiky je dle Hadota nicméně oproti ostatním občanům chápán jako bytost zvláštní a podivínská, jelikož se rozchází se zvyklostmi a obyčeji běžných smrtelníků. Viz Hadot (2012, česky 2019, s. 21).

11 Hadot tímto výrazem míní různé praktiky charakteru tělesného, jako je například stravovací režim, řádu diskurzivního, jako je dialog či rozvažování, anebo řádu intuitivního, jako je kontemplace. Jejich společným cílem je dosáhnout vnitřní proměny toho, kdo se jim věnuje. Viz Hadot (2012, česky 2019, s. 17).

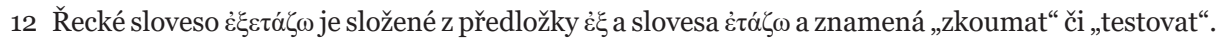
Etymologicky se jedná o denominativum (tj. slovo odvozené od podstatného nebo př́davného

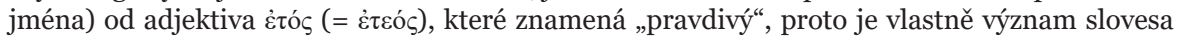

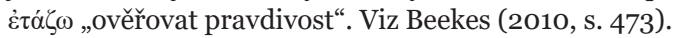

13 Viz Irwin (2007, s. 121).

14 Metoda spočívá v demonstraci kontradikce a v jakémsi odmaskování dotazovaného od nánosů jeho klamných názorů.

15 Dle sókratovsko-platónské tradice člověk v sobě jaksi má vědění a v průběhu života si na ně pomocí různých technik i kontextů rozpomíná (anamnésis). Maieutická metoda je spíše pozitivní projekt, ve kterém jde o to zvědomovat a formulovat vědění spíše než ho zpochybňovat.

16 Viz Platón (2005, 38a). 
Kořeny a ideové ukotvení filosofické praxe $\mathrm{v}$ českém prostředí lze hledat u tzv. filosofie provádějící. Spolu s N. Pelcovou ji můžeme charakterizovat jako filosofii, ,jejímž cílem je kultivovat, proměňovat a vychovávat člověka, pěstovat jeho lidské a občanské ctnosti, rozvíjet tvorbu ve vztahu ke světu a sebetvorbu ve vztahu k sobě samému“. ${ }^{17}$ Patočka filosofií provádějící nazýval filosofii výchovy, s odkazem na Platóna to byla péče o duši člověka. ${ }^{18}$ Filosofickou praxi vnímáme jako na teoretické rovině velmi blízkou filosofii provádějící. Hlavní rozdíl spatřujeme v samotném provádění. Zatímco filosofie provádějící je pro člověka určitou oporou a průvodcem na jeho životní cestě a znamená v zásadě život ve zkoumání sebe sama (Sókratés), filosofická praxe je konkrétní realizací daného zkoumání, když používá specifické metody, nástroje a postupy, které člověka $\mathrm{k}$ tomuto cíli vedou. Mưžeme ji tedy označit za praktické vyústění filosofie provádějící.

\section{Filosofická praxe v ČR: dosavadní stav bádání a realizace}

Výzkum a samotná realizace filosofické praxe je v České republice na začátku. Existují studentské práce, které se věnují vybraným oblastem a tématům $\mathrm{z}$ dané disciplíny a které českému čtenáři představují myšlenky zahraničních filosofických praktikantů. Př́lkladem jsou bakalářská a diplomová práce I. Koptové (Filosofické poradenstuí, 2012; Co je specifické pro filosofické poradenství?, 2014), bakalářská práce T. Helmicha (Filosofická praxe a poradenství, 2013) či diplomová a disertační práce O. Horáka (Buberov koncept Ty ako spôsob života. Možnosti aplikácii vo filozofickom poradenstve a d'alších oboroch, 2010; Filozofické poradenstvo - kritika, 2014), která vyšla rovněž v podobě monografie. ${ }^{19} \mathrm{~J}$. Peregrin publikoval zprávu o filosofickém poradenství s názvem Filosofické poradenství, vzkvétající živnost. ${ }^{20}$

17 Pelcová (2020).

18 Viz Blecha (2015). Na práci J. Patočky navázala mj. filosofka J. Pešková, která zdůrazňovala nepostradatelnost filosofie pro náš život a v podobě filosofie provádějící ji aplikovala v běžném životě.

19 Viz Horák (2015). Publikaci je možné označit za selektivní kritiku filosofického poradenství, které autoři textu řadí k nejproblematičtějším oblastem filosofické praxe.

20 Viz Peregrin (2010). Spíše než seriózním vyjádřením k filosofické praxi je zpráva satirickým a ironizujícím vyjádřením k filosofickému poradenství. Mnohdy vtipným způsobem upozorňuje na nedostatky této kontroverzní oblasti filosofické praxe. 
Filosofické konzultaci ve sportu se věnoval ve svém prríspěvku L. Mareš. ${ }^{21}$ Postřehy a osobní zkušenosti s filosofickou praxí zpřístupňuje na svém blogu formou osobních zápisků D. D. Novotný. ${ }^{22}$

$S$ větším množstvím materiálů se lze setkat $\mathrm{v}$ případě filosofie pro děti (P4C). Jmenujme např́íklad bakalářskou práci L. Hubené (Srovnání př́stupu M. Lipmana a O. Brenifiera $k$ filosofování s dětmi, 2013), bakalářskou práci E. Brisudové (Filozofie pro děti jako součást rozvíjení myšlení a emoční inteligence dětí prèedškolního věku, 2016), bakalářskou práci J. Hořejší (Filozofie pro dětiv MŠ Větrná, 2018), diplomovou práci J. Vlasákové (Filozofie pro děti na 1. stupni ZŠ, 2012), diplomovou práci B. Odehnalové (Filosofie pro děti jako koncepce výuky náboženstuí a katecheze, 2016) či diplomovou práci V. Jozové (Filosofie pro děti jako prostředek etické výchovy zahrnující různé oblasti života dítěte $v$ mladším školním věku, 2018). Pod hlavičkou Jihočeské univerzity existuje Centrum Filozofie pro děti, které vydalo překlady metodických textů i vlastní texty pro filosofování s dětmi, pořádalo vzdělávací kurzy pro učitele a zprostředkovávalo setkání s odborníky v dané oblasti.. ${ }^{23}$

Výzkum v oblasti filosofické praxe probíhá rovněž na Slovensku. Zde je potřeba zmínit autory B. Šulavíkovou a J. Šulavíka, kteří svými odbornými př́íspěvky zprostředkovávají vhled především do oblasti filosofického poradenství. Reflektujeme-li však samotnou realizaci filosofické praxe na území Česka či Slovenska, lze konstatovat, že se jedná prozatím o ojedinělý fenomén. Aktivně rozvíjet filosofickou praxi se pokoušejí autoři tohoto př́spěvku. Od dubna 2017 pořádají na Teologické fakultě Jihočeské univerzity pravidelně filosofické workshopy určené pro studenty, akademické pracovníky i širokou veřejnost. Rovněž navštěvují základní a střední školy v Českých Budějovicích a blízkém okolí, kde filosofují se studenty nad vybranými tématy. Této iniciativě se věnují také na univerzitě, a to v rámci projektu Dětské a Juniorské univerzity. ${ }^{24}$

21 Viz Mareš (2019).

22 Pro více informací viz Novotný, D. D. Poznámky pod čarou. Analyticko-scholastické drobky postmoderního tradicionalisty [Online]. Hledat: „filosofická praxe“ [cit. 13. 1. 2020]. Dostupné na: http://poznamkypodcarou.blogspot.com/search/label/filosofick\%C3\%A1\%2opraxe.

23 Pro více informací viz Centrum Filozofie pro děti. Filosofie pro děti. V centru pozornosti ... myšLenka. [Online]. Jihočeská univerzita $v$ Českých Budějovicích, Katedra pedagogiky TF, České Budějovice [cit. 31.1. 2020]. Dostupné na: http://www.p4c.cz/.

24 Jedná se o celouniverzitní projekt, který se snaží žáky a studenty vtáhnout do univerzitního 
Mimoto nabízejí studentům a zaměstnancům Jihočeské univerzity možnost absolvovat filosofickou konzultaci. ${ }^{25}$ Autoři neznají nikoho dalšího, kdo by v současnosti filosofickou praxi (vyjma filosofie pro děti) systematicky na území České republiky provozoval. Objevují se semináře či kurzy, které mají k probírané disciplíně minimálně blízko (nap̌r. rozvoj kritického myšlení, semináře a společná čtení v kavárnách, filosofické rozpravy studentů a vyučujících jako doplňkové semináře), žádná z těchto událostí se ovšem k filosofické praxi explicitně nehlásí a neodkazuje přímo k metodám jejích zástupců.

\section{Filosofie pro děti}

Program filosofie pro děti založil americký filosof M. Lipman ${ }^{26}$ (19232010). Jeho snaha cílila na to, aby děti ve škole byly schopné lépe argumentovat, reagovat na druhé a klást si otázky. Filosofie pro děti, tak jak ji chápeme v tomto textu, však není pouze Lipmanovou metodou. ${ }^{27}$ Lipman však nejlépe vycítil onu potřebu, která se v jeho době a v jeho pedagogické praxi ukazovala jako důležitá. Mnoho zástupců filosofické praxe pracuje kromě dospělých a dospívajících také s dětmi. Např. O. Brenifier, ${ }^{28}$ známý francouzský filosofický praktikant, má oproti Lipmanovi odlišnou metodu práce s dětmi, ve které vystupuje více do popředí spíše jedinec než skupina. Důležité je také zmínit, že právě u dětí je velký transformující a obohacující potenciál v jejich vlastním myšlení - mohou se naučit tázat, hledat odpovědi a naslouchat druhým, což je pro jejich další rozvoj podstatné.

dění a zprostředkovat jim akademická témata dostupným způsobem. Viz Teologická fakulta, Jihočeská univerzita $v$ Českých Budějovicích [Online]. (C)2020 [cit. 31. 5. 2020]. Sekce „Podrobné informace o kurzech“ Dostupné z: https://www.tf.jcu.cz/zajemci-o-studium/ celozivotni-vzdelavani/podrobne-informace-ke-kurzum.

25 K začátku roku 2020 uskutečnili autoři textu přes 40 workshopů s dětmi, studenty a dospělými. Rovněž dohromady vedli přes 10 filosofických konzultací se studenty univerzity a jejími pracovníky či absolventy.

26 M. Lipman spolu s A. M. Sharp vymyslel a dále rozvíjel pedagogickou metodu filosofie pro děti. Jako začátek této tendence můžeme datovat vydání filosofického příběhu Harry Stottlemeier's Discovery v roce 1971.

27 Filosofování s dětmi se věnují rovněž B. Børresen a B. Malmhester či S. Stanley.

28 Viz „Philosophy with children.“ In Institute de Practiques Philosophiques [Online] [cit. 23. 1. 2020]. Dostupné na: http://www.pratiques-philosophiques.fr/en/pratical/philosophy-withchildren. 
Obecně lze říci, že filosofie pro děti vypadá v praxi tak, že děti obvykle sedí v kruhu, který symbolizuje rovné př́ležitosti a napomáhá lepší komunikaci jak akustické, tak vizuální. Na začátku se čte příběh. Děti se tak zdokonalují nejen ve čtení, kdy každé z nich čte jednu větu nebo část textu, ale i v naslouchání druhým. Filosofické příběhy často obsahují postavy a témata, která vyvolávají otázky. Po přečtení určité části knihy pokládají děti otázku, která souvisí přímo s textem, nebo nějak vychází z jejich vnímání textu. Při této fázi je zásadní, aby se tvořily otázky filosofické, ne triviální. Poté se demokraticky volí otázka, která se bude probírat. Následující diskuse, která v důsledku nemá být pouze diskusí, ale také dialogem, je stěžejní částí každé filosofie pro děti. Tato část nejde připravit, předpovědět či upravovat tak, jak bychom dopředu zamýšleli. Je důležitá zejména kvo̊li tomu, že je to prostor, ve kterém filosofujeme - snažíme se vyřešit spolu s druhými nějakou otázku či problém. V závěrečné (reflexivní) části by mělo dítě zhodnotit své dosavadní myšlení (jeho vývoj), názory druhých, ale také přípravu a průběh cvičení samého. Hodina filosofie pro děti má určitou strukturu. Nejčastěji se jedná o tři podstatné části (aktivizace, otázky, dialog/diskuse), které bývají dále upravovány či opakovány v návaznosti na danou větev filosofie pro děti.

Základním cílem filosofie pro děti je dle M. Lipmana rozvoj myšlení. To se děje na třech úrovních. První je tvořivé (kreativní) myšlení, které hledá alternativy, důsledky, analogie a vztahy. Druhé je kritické myšlení, které vyvozuje, hlídá samo sebe (tzv. autokorekce), hledá kritéria situace a její východiska. Poslední je myšlení angažované, které ověřuje hypotézy, definuje pojmy či s odstupem a z jiného úhlu na věc pohlíží. ${ }^{29}$ Dále se v dětech probouzí zásady argumentace při diskusi a dialogu s druhými stejně tak, jako se zlepšuje cit pro komunikaci jako takovou v její verbální i neverbální formě. A tak se například děti učí nejenom mluvit a naslouchat, ale i mlčet nebo se nebát promluvit, pomoci druhému a nebo se nebát zeptat, když druhému nerozumíme (mějme však na paměti, že rozumět neznamená souhlasit). Dítě tak získává klíčové kompetence, které může využít i mimo hodinu filosofie a trrídu.

29 Viz Centrum Filozofie pro děti (2O2O). 
M. Lipman chce, v návaznosti na J. Deweyho, přeměnit školní třídu v hledající společenství či zkoumající komunitu (community of inquiry). ${ }^{30}$ Jedná se o situaci, kdy děti společně hledají pravdu na jimi vybranou otázku. Především jde o vzájemné naslouchání, vyměňování názorů a hledání řešení. Ten, kdo danou skupinu vede, by měl vystupovat v roli facilitátora a měl by být spíše součástí skupiny než garantem pravdy či někým, kdo stojí striktně mimo ostatní. Jeho úkol je zapisovat myšlenky na tabuli, rekapitulovat řečené, pokládat dílčí otázky, upozorňovat na předpoklady a protiřečení apod.

Filosofické příběhy, které se využívají ve filosofii pro děti, mají dát dostatečný literární (narativní) prostor pro filosofování s dětmi. Aby byl prostor také filosofický, musí být takový, aby oslovil děti a podnítil je k tázání. Musí být dítěti blízký. Nemá se jednat o pohádku či o naprostou fikci. Reálné postavy řeší (reálné) problémy a sami hledají odpověd' na své otázky. Příběh by měl obsahovat filosofická témata, nejednoznačné otázky, situace a dialogy postav. V dnešní situaci ovšem v rámci filosofie pro děti lze využít i knihy, které nejsou pouze filosofickými příběhy. Jedná se především o obrázkové knihy různých spisovatelů a ilustrátorů. ${ }^{31}$

\section{Filosofický workshop}

Filosofický workshop je společná aktivita zaměřená na filosofické přemýšlení, porozumění určitému tématu a na individuální i skupinový myšlenkový rozvoj. Na rozdíl od konzultací probíhá ve větším počtu účastníků (obvykle mezi 5 a 20 lidmi). Během workshopu se filosofickým způsobem řeší atraktivní a důležitá témata. ${ }^{32}$ Tematicky není workshop omezen. Za hlavního garanta a vodítko rozhovorů je obvykle považována racionalita.

30 J. Dewey (1859-1952) spolu s C. S. Peircem (1839-1914) jako první zavedli pojem community of inquiry. Pro kontext v programu filosofie pro děti viz Lipman (1993, s. 606-614).

31 Filosofické příběhy (povídky) známých propagátorů filosofie pro děti byly přeloženy do českého jazyka díky Centru filozofie pro děti (při Teologické fakultě Jihočeské univerzity v Českých Budějovicích), zmiňme např. Sharp (2000, 2005).

32 Mezi témata, která jsme doposud s účastníky řešili, patří: politická filosofie („Je demokracie nejlepší způsob vlády?“, „Jsme národní stát?“), „Co má v životě smysl?“, „Člověk a jeho nábožensko-mytologický výklad skutečnosti“, „Sókratés“, „Čas“, „Jíst, či nejíst maso?“, „Filosofování o sportu“, „Hodnota peněz“, „Jaká je dnešní doba?“, „K čemu poznávat sám sebe?“, „Odpouštět, či neodpouštět?“, „Odpovědnost za přírodu“, „Etická dilemata“ ad. 
Filosofický workshop se zaměřuje na rozvoj porozumění určité oblasti včetně tázajícího se člověka a na pravdivé uchopování skutečnosti. Zaměřuje se ale také na rozvoj tzv. měkkých dovedností. Mezi ně řadíme racionální uvažování, kooperaci, sebereflexi, tvůrčí řešení problémů, strukturované myšlení, konstruktivní kritičnost a schopnost přijímat kritiku, schopnost adaptace, samostatnost, orientaci v informacích, morální reflexi, ale i schopnost aktivně naslouchat a reagovat na řečené spíše než na domyšlené a zkreslené. Ve filosofickém workshopu se člověk učí koexistenci založené na toleranci, vzájemném respektu, odpovědnosti a nediskriminaci. Učí se rozvíjet to, co považujeme za bytostně lidské, tedy schopnost vedení dialogu. Ten zahrnuje schopnost naslouchat, adekvátně reagovat na řečené, ale i formulovat vlastní přesvědčení a rozumově ho podložit. $V$ rámci filosofického workshopu se lidé učí přemýšlet filosofickým způsobem, tj. učí se rozumově uchopovat konkrétní téma. Jelikož je workshop postaven na skupinovém dialogu ${ }^{33}$, rozvijí u účastníků rovněž schopnost prezentovat své myšlenky ve skupině, adekvátně reagovat na druhého a orientovat se ve skupinovém rozhovoru.

Vedoucím workshopu je facilitátor (obvykle 1 až 3 lidé), jehož role se liší podle cíle workshopu. Jeho základní úlohou je naplánovat a představit rámec workshopu, řídit či korigovat rozhovory, zapisovat myšlenky účastníků a vhodně je vyzdvihovat. Existuje více přistupů k filosofickým workshopům. Naše metoda je umírněná verze filosofického workshopu O. Brenifiera ${ }^{34}$ doplněná o určité prvky z filosofie pro děti (Lipman, Børresen, Malmehester). ${ }^{35}$

Filosofický workshop, na rozdíl od filosofie pro děti v lipmanovském duchu či filosofování s dětmi v podání O. Brenifiera, přesahuje školní prostředí. Oproti filosofickému workshopu je filosofie pro děti zaměřena na práci s mladšími dětmi a na osvojování si základních myšlenkových

33 Jedná se o takový typ rozhovoru, kdy účastníky spojuje konkrétní téma, o kterém hovoří, a zároveň dodržují obecná pravidla dialogu, jakými jsou ochota naslouchat, porozumět, podrobit kritickému zkoumání vlastní přesvědčení a snaha přispět k porozumění určitému tématu či navrhnout řešení (nikoli vyhrát spor).

34 Viz Brenifier (The Art of Philosophical Practice).

35 Se zmíněnými praktikanty mají autoři praktickou zkušenost díky návštěvě jejich seminářů a rovněž díky studiu textů a jejich aplikaci do praxe. 
dovedností. Filosofický workshop stojí na filosofických základech, resp.je důslednější, náročnější a využívá pestřejší paletu nástrojů a dovedností. Rozvíjí osobnost člověka pro život díky používání filosofických nástrojů a je obvykle určen pro dospělé lidi. ${ }^{36}$ Ve filosofii pro děti je kladen větší důraz na aktivizaci skupiny (stimulující aktivity i nefilosofického charakteru) a na propojení se skupinou. Vefilosofickém workshopujevětší důraz kladen na proces přemýšlení - tj. na správné užívání filosofických nástrojů $\mathrm{v}$ podobě konceptualizace, argumentace, problematizace, syntézy, tvorby myšlenkových experimentů, interpretace, evaluace či reflexe a na pohybování se na filosofických rovinách (abstraktní/obecné, kritické a tematicky otevřené).

$\mathrm{V}$ př́padě lipmanovského př́stupu se facilitátor stará o to, aby se skupina jako celek posouvala kupředu v řešení otázky, aby důležité myšlenky nezapadávaly a zapojovali se pokud možno všichni. Používá přitom sumarizaci, reflexi a pestrou sérii otázek. Ideálem je, že skupina po čase řídí workshop do velké míry sama a facilitátor se stává jedním z účastníků. Dalším ideálem workshopu je to, když skupina usilovně přemýšlí a facilitátor není bezprostředně zaneprázdněn myšlenkovým úsilím, takže má kapacitu na sledování dění z dostatečného odstupu na to, aby dokázal rozpoznat zacyklenost či dokázal přijít s konstruktivním nápadem.

V rámci brenifierovského př́stupu se facilitátor snaží o individuální rozvoj určitého člena skupiny (případně více členů). Smyslem není až tak společné hledání, ale individuální posun a určité prozření účastníků. Facilitátor $\mathrm{v}$ rámci workshopu $\mathrm{v}$ tomto případě volí strategii dílčích konzultací, je přímočarý, dbá na koherentnost a stručnost výpovědí a použíá skupinu jako nástroj pro demonstraci „selského rozumu“ (common sense). ${ }^{37}$ Je autoritou, která drží otěže workshopu ve svých

36 Lze říci, že pro jedince od věku střední školy, kteři jsou schopni komplexněji a abstraktně přemýšlet.

37 Koncept common sense (zdravý, selský či přirozený rozum) je vhodným nástrojem pro demonstraci sdílené racionality/objektivity a pro eliminaci osobních myšlenkových výstřelků. Jeho rizikem, na které upozorňuje např. S. Hawking (Brief Answers to the Big Questions) je to, že pracuje s momentálním chápáním toho, co je přijímáno jako racionální, a neumožňuje tak myšlenkovou kreativitu, která začíná obvykle v iracionalitě a vede k vytvoření nové racionality. Argument proti této námitce může být to, že common sense je v zásadě neměnný a použitelný ve stejné podobě i v odlišných kontextech, tj. odkazuje $\mathrm{k}$ těm nejzákladnějším mechanismům $\mathrm{v}$ realitě a v naší mysli. 
rukou. Během workshopu je kladen důraz na to, jak lidé přemýšlejí, nikoli na to, co si myslí - obsah je tedy řazen na druhou kolej. ${ }^{38}$ Skupina se využívá jako zrcadlo a nástroj pro formování jednotlivce a pro demonstraci jeho myšlení. Pracuje se na postojích (attitudes) a kompetencích (competencies). ${ }^{39} \mathrm{~V}$ této formě vedení skupiny je facilitátor i konfrontační, a to s cílem nastavit jednotlivému účastníkovi workshopu zrcadlo, aby v něm viděl sebe samého. $4^{40}$

$\mathrm{Na}$ našich workshopech, pořádaných na Teologické fakultě JU, se zaměřujeme především na skupinovou práci, která má vyústit ve schopnosti lépe argumentovat, ujasňovat si pojmy a přiblížit se odpovědi na probíraný problém či otázku. Téma workshopu je obvykle předem dané a jako facilitátoři navrhujeme i metodický postup pro jeho řešení. Zůstáváme ovšem otevřeni návrhům na změnu ze strany účastníků. Oproti brenifierovskému přístupu klademe větší důraz na práci s filosofickým obsahem než na práci s postoji účastníků. Hledání odpovědi nemusí být vždy jednoduchý, jednomyslný a krátký proces, ale přesto se jedná o nejzákladnější filosofickou dovednost - tázat se a pokoušet se odpovídat. Neméně důležitou součástí je i naslouchání a porozumění tomu, co druhý říká. Při workshopech využiváme také metody zážitkové pedagogiky, psychologie, koučinku či dalších př́ibuzných oblastí. Jedním z dalších cílu je také poznávat jiné (lidi, argumenty, procesy myšlení), což může pomoci pochopit jak ostatní účastníky, tak v konfrontaci s jinakostí i sebe sama. Filosofický workshop lze vnímat jako určitou „oázu“ určenou pro důsledné přemýšlení, která je na jedné straně oddělena od každodenní reality, na druhé straně ji má jako předmět svého zájmu a z odstupu ji reflektuje.

38 Námitkou zde může být, zda je při nedostatečném zohledňování obsahu možné hovořit o workshopu jako o filosofickém.

39 Viz videorozhovor s V. Chernenko, ruskou filosofickou praktikantkou patřící do brenifierovské školy filosofické praxe: Lahav (2014).

40 Tato forma vedení je blízká vedení polemiky, např. při politických debatách, kdy je cílem zjistit přesvědčení druhých, případně i poukázat na nekoherentnost či nejasnost myšlení druhého. Moderátor veřejných debat oproti tomuto přístupu spíše dbá na vytvoření př́ijemného a bezpečného prostředí, pomáhá mluvčím se smysluplně a konstruktivně vyjadřovat a dbá na plynulý chod debaty. Tímto svým přístupem se spíše blíží lipmanovskému přístupu. 


\section{Filosofická konzultace}

Zatímco filosofická praxe jako celek vychází z antické tradice, kritéria vymezení filosofické konzultace by měla být odvozována především z doby současné a reagovat na vědecké poznání oborů, jako je např́íklad psychologie, která byla ještě do 19 . století $^{41}$ považována za součást filosofie. Za takové kritérium považujeme filosofičnost, ptáme se, co zbylo filosofii, když se z ní vydělily specializované vědy, co je na filosofické konzultaci filosofického? Filosofická by měla být jak forma, tak i obsah konzultace. Považujeme za důležité zdůraznit, že filosofie v jakékoliv formě není pomáhající profesí. ${ }^{42}$ Filosofie sama ani filosofické konzultace nemohou ze své podstaty zaručit a ani tedy slíbit člověku takovou pomoc, jakou nabízí například psychoterapeut, sociální pracovník nebo lékař. Filosofická konzultace nemá za cíl člověku pomoci cítit se lépe nebo vyřešit nějaký osobní problém, to se však může stát náhodným nebo vedlejším produktem. J. Šulavík, který se vyjadřuje $k$ terapeutickému efektu filosofické interpretace, píše, že tento efekt není primárním cílem filosofie, ale sekundárním důsledkem její celkové kognitivní aktivity. ${ }^{43}$

Filosofickou pomoc naopak slibuje filosofické poradenství, ${ }^{44}$ které $\mathrm{v}$ širším pojetí dokonce zahrnuje i pomoc $\mathrm{s}$ duševními onemocněními. 45 Filosofické poradenství kritizuje O. Horák, který popisuje jeho rizika pro klienty, kteří se svěřují do péče filosofưm bez adekvátního vzdělání v psychologii nebo psychiatrii a riskují tak své duševní zdraví v rukou člověka, který vede poradenské sezení převážně podle své intuice a na základě technik bez empirické evidence. ${ }^{46}$ Je doporučeno, aby každý filosofický konzultant měl minimálně magisterské vzdělání ve filosofii. ${ }^{47}$

41 Viz Nakonečný (1995).

42 Tímto výrokem míníme, že ačkoli filosofie člověku určitým způsobem pomoci může (např. porozumět určitému tématu, rozvíjet myšlenkové dovednosti či získat vědění), ze své podstaty není jejím cílem pomáhat způsobem, jakým pomáhají profese k tomuto účelu zaměřené.

43 Viz Šulavík (2001, s. 588).

44 Mezi nejznámější filosofické poradce patří L. Marinoff, P. B. Raabe či S. Schuster. Z organizací stojí za zmínku American Philosophical Counseling Asociation (APCA) či American Philosophical Practicioners Asociation (APPA) či American Society for Philosophy, Counseling, and Psychotherapy (ASPCP).

45 Viz Louw (2013, s. 64).

46 Viz Horák (2015, s. 46).

47 NPCA (2014). 
Také by měl být vybaven vlastnostmi vhodnými pro práci s klientem v dialogu, jakými jsou otevřenost, schopnost naslouchat, pohotovost, důslednost, pozornost. Konzultant by také měl mít alespoň základní znalost člověka z psychologického hlediska, aby rozuměl dopadu jeho působení na psychiku klienta a $\mathrm{v}$ př́padě potřeby doporučil klienta kompetentnějšímu odborníkovi.

Filosofie není pomáhající profesí, to ale neznamená, že vůbec nepomáhá. Pomáhá člověku projasňovat myšlení, prohlubovat porozumění určitému tématu, měnit životní perspektivy, hlouběji si uvědomovat souvislosti a stimulovat $\mathrm{k}$ důslednému přemýšlení o tématech na filosofické rovině. Konzultace je cvičením v přemýšlení. Filosoficky přemýšlet znamená racionálně reflektovat skutečnost z odstupu za využití určitých myšlenkových operací. Mezi ně patří argumentace, uvádění př́kladů, analýza, problematizace, konceptualizace, tvorba hypotéz či klarifikace. Argumentací rozumíme logicky platné zdůvodňování tvrzení. ${ }^{8}$ Analýzou myslíme důsledné zkoumání problému a zohledňování perspektiv. Problematizace představuje hledání limitů tvrzení. Konceptualizace je uchopování řešeného problému pomocí konceptu. Tvorbou hypotéz rozumíme formulaci předběžných racionálních odpovědí, které následně vybízejí k prověření a argumentačnímu podložení. Klarifikace je proces, kdy klient reformuluje své tvrzení za účelem jeho projasnění.

Ve filosofické konzultaci se proces rozhovoru odehrává ve formě dialogu. ${ }^{49}$ Př́ístupů $\mathrm{k}$ filosofickým konzultacím nebo filosofickému poradenství je dnes celá řada a liší se svou formou, obsahem i cíli. Následující popis zachycuje podobu konzultace, kterou se pokoušíme rozvíjet. Filosofický dialog probíhá mezi konzultantem a klientem. Dialog je zahájen tím, že klient položí jasně formulovanou otázku, která prezentuje filosofický problém či dilema. Od otázky se celá konzultace odvíjí a jejím vyřešením je konzultace uzavřena. Otázka se zpravidla zapisuje, aby se $\mathrm{k}$ ní během konzultace bylo možné vracet. Je totiž možné, že se během dialogu pozornost obrátí k jinému tématu. Zapsání

48 Viz Novák \& Dvořák (2007, s. 141).

49 Zahrnuje tedy otevřenost, aktivní snahu porozumět, společně tvořit v procesu vzájemné podpory i kritického náhledu, a to s důsledným následováním přirozeného rozumu. Nejedná se o rozhovor s cílem porazit druhého (debata), obhájit vlastní přesvědčení (disputace), ani o volné povídání bez cíle a pravidel (volná diskuse). 
otázky také slouží klientovi k tomu, aby si ujasnil, na co se chce zeptat, a svůj zájem na papíre ve formě otázky ohraničil. Jedná se o úvodní konceptualizující a klarifikující cvičení. Vyřešení dané otázky znamená, že klient dané téma promyslí takovým způsobem, že mu bude lépe rozumět a že odpovědi, které během konzultace nalezne, ho budou stimulovat k dalšímu samostatnému přemýšlení. Po prvotní otázce klienta pak další otázky pokládá konzultant a klient na ně hledá odpovědi. V případě, že prvotní otázka není jasně formulována, je věnován čas k upřesnění formulace. Klienti se také mohou vyhýbat formulaci otázky a namísto toho vysvětlují, co chtějí konzultovat. Může se stát, že klient položí otázku nevhodnou pro filosofickou konzultaci. Nevhodná je otázka, která není filosofická nebo na niž je zřejmá odpověd'. S takovými otázkami se ve filosofické konzultaci pracuje tak, že místo hledání odpovědi na takovou otázku bude konzultant hledat motivaci pro její položení. Na základě toho lze formulovat otázku novou, která explicitně zachytí filosofický obsah a která se stane hlavním tématem konzultace. ${ }^{50}$

Proces hledání motivace je nosným pilířem filosofické konzultace. Motivace pro dané téma se často řeší na začátku, když se konzultant zeptá, proč se klient na takovou věc dotazuje, nebo když konzultant klienta nechá vymyslet předpoklady ke kladení takové otázky. O. Brenifier svá sezení s klienty začíná otázkou „Proč jsi tady?“, která má klienta přivést k reflexi a sebe-vyjádření, je to také zástupná otázka pro „Jakou sis připravil otázku?" “. ${ }^{1}$ Motivace je pro konzultaci zásadní v tom smyslu, že obsah konzultace by měl být něčím, co klienta doopravdy zajímá, něco, co je mu blízké a na čem mu záleží. $V$ takovém případě má filosofickou konzultaci význam podstupovat, protože pouze tehdy může klientovi přinést něco hodnotného. Centrálním tématem a cílem filosofování je dobrý život, ${ }^{2}$ a proto by klient do konzultace měl přjít s takovou otázkou, jejíž zodpovězení přispěje k jeho dobrému životu. Pro návštěvu filosofického konzultanta se předpokládá prvotní údiv a zájem o poznání.

50 Příklad nevhodné otázky vyžadující reformulaci: „Co mám dělat se svým životem?“ (otázka spadající do oblasti koučinku a psychologie, možná reformulace: „Co má v lidském životě smysl?“) či „Proč jsou rostliny zelené?“ (otázka spadající do oblasti botaniky, možná reformulace: „Proč jsou jevy v realitě právě takové, jaké jsou?").

51 Viz Brenifier (The philosophical consultation, s. 38-39).

52 Viz Šulavíková (2011, s. 158). 
Filosofická konzultace není debatou, protože pointou konzultace není bojovat o předem rozhodnutou pravdu. Předpokladem filosofování je mít otevřenou mysl a být schopen kriticky a objektivně přemýšlet. Klient by měl být schopen poodstoupit od sebe samého a podívat se na téma z odstupu.

S jasně formulovanou otázkou klienta se může dále pracovat, nebot’se tak stane řešitelným teoretickým problémem. Teoretickým problémem rozumíme i např́klad etická dilemata a otázky jinak spadající do praktické filosofie: „Může člověk v životě lhát, aniž by to bylo morálně špatné?" Praktickým problémem by byla otázka spadající do kompetencí např́klad psychoterapeuta: „Jak se mohu zbavit nervozity při veřejném vystupování?“ Nově formulovaná otázka bude muset být filosofická, to znamená, že se bude moci řešit $\mathrm{v}$ abstraktní rovině nebo že bude řešit obecné pojmy. Tak by tomu bylo např́lklad u otázek „Je demokracie nejlepší způsob vlády?“ nebo „Jak se má občan v rámci demokracie odpovědně chovat?“. Může se stát, že klient položí otázku osobní. Veškeré individuální nebo konkrétní problémy se budou řešit vzhledem $\mathrm{k}$ rozsahu obecného nebo abstraktního pojmu. ${ }^{53}$ Nejprve se tedy bude v konzultaci řešit vymezení obecného nebo abstraktního pojmu a potom se lze vrátit $\mathrm{k}$ individuálnímu nebo konkrétnímu pojmu a vztáhnout je na sebe. Klientova otázka „Jsem spravedlivý člověk?“ by se řešila nejprve otázkou „Co je to spravedlnost?“ a následně by konzultant položil otázku „Jsi tedy ty spravedlivý člověk?" a nechal by klienta argumentovat ve prospěch své odpovědi. Konzultant př́padně argument problematizuje. ${ }^{54}$ Setkání s filosofickým konzultantem může proběhnout jednorázově, případně může být pravidelné. Využití konzultace se nabízí pro toho,

53 Odlišný přístup k filosofickým konzultacím má francouzský filosofický praktikant O. Brenifier a jeho škola. Konzultace je pro něho především nastavováním zrcadla klientovi, směřuje k projasňování myšlení, práci na rozvoji osobního postoje a kompetencí. Brenifierův přístup má svou povahou velmi blízko k psychologii, jelikož mu spíše než o řešení obsahu jde o práci s klientem a jeho myšlením. Pro více informací viz stránky: Institute of Philosophical Practices [Online] [cit. 23. 1. 2020]. Dostupné z: https://www.pratiques-philosophiques.com/eng. A stránky: Lecoq, J. (2019b): „The Philosophical consultation.“ In Dialogon [Online] Paris, (C) 2019 [cit. 25. 1. 2020]. Dostupné na: http://dialogon-en.ugal.com/the-philosophicalconsultation.

54 Kromě popsaného modelu filosofické konzultace existuje rovněž model, který můžeme nazvat jako společné filosofování. V něm konzultant nejen pokládá otázky, ale i prezentuje vlastní myšlenky a vhledy a s klientem filosofuje společně. Tento proces je nosný v tom, že může do konzultace vnést poměrně rychle kvalitní obsah a zefektivnit proces filosofického hledání. 
kdo má zájem důsledně uchopit pro něj důležité téma filosofickým způsobem. Konzultace není manipulativní praktikou s čistě utilitárními cíli, ale spíše otevřenou platformou pro důsledné filosofické přemýšlení.

\section{Závěr}

Filosofická praxe představuje pro současné české prostředí novou výzvu. Z pohledu akademické filosofie se jedná o výzvu systematicky uchopit danou disciplínu, teoreticky identifikovat její místo ve filosofické tradici a především vyrovnat se s nárokem na praktický význam filosofování $\mathrm{v}$ životě člověka. $Z$ pohledu psychologie a příbuzných oblastí (koučink) lze výzvu chápat ve smyslu vymezení hranic, kdy se jedná o filosofickou a kdy již o psychologickou praxi. Popisovaná disciplína se na skupinové rovině významně dotýká rovněž pedagogiky. Představuje možnost inovace $\mathrm{v}$ př́stupu $\mathrm{k}$ výuce žáků a studentů. Zatímco filosofie pro děti (P4C) je ve školním prostředí samotnými učiteli využívána, realizace filosofických workshopů je na školách teprve v začátcích.

Reflektujeme-li filosofickou praxi na území České republiky, můžeme dospět k otázkám, na které bude s ohledem na možný budoucí rozvoj dané disciplíny žádoucí hledat odpovědi racionální i empirickou cestou. Jaké jsou ontologické, gnoseologické, axiologické a etické předpoklady dané praxe? Jaký význam má filosofování s žáky a studenty pro jejich osobnostní rozvoj? Jak konkrétně lze využívat filosofickou konzultaci? S ohledem na skutečnost, že filosofická praxe není marginální, nýbrž celosvětově populární a rozvíjející se fenomén, považujeme za žádoucí, aby byla zkoumání této disciplíny věnována větší pozornost.

\section{Literatura}

Beekes, R. (2010): Etymological Dictionary of Greek. Brill, Leiden, Boston.

Blecha, I. (2015): „Patočkova péče o duši mezi Sókratem, Platónem

a Aristotelem." Filozofia 70 (6): 409-419.

Brenifier, O. „The Art of Philosophical Practice.“ In Institute de

Practiques Philosophiques [Online] [cit. 23.1. 2020]. Dostupné 
z: http://www.pratiques-philosophiques.fr/wp-content/ uploads/2015/o8/The-art-of-philosophical-practice-mise-enpage-1.pdf.

Brenifier, O. The Philosophical Consultation. Editions Alcofribas.

Dostupný také z: http://www.pratiques-philosophiques.fr/ wp-content/uploads/2020/o1/Philosophical-consultation-lastversion.pdf.

Centrum Filozofie pro děti. (2020): Filosofie pro děti. V centru pozornosti ... myšLenka. [Online]. Jihočeská univerzita $v$ Českých Budějovicích, Katedra pedagogiky TF, České Budějovice, (C) 2020 [cit. 31. 1. 2020]. Sekce: „Co je Filozofie pro děti“Dostupnéz: http://www.p4c.cz/index.php?s=o-projektu.

Hadot, P. (2012): Éloge de la philosophie antique. Éditions Allia, Paris; český překlad (D. Bartoň) Chvála antické filosofie, Rybka publishers, Praha, 2019.

Hadot, P. (1995a): Philosophy as a Way of Life. Blackwell's, Oxford.

Hadot, P. (1995b): Qu'est-ce que la philosophie antique? Gallimard; český překlad (M. Kř̌̌žová) Co je antická filosofie?, Vyšehrad, Praha, 2017.

Horák, O. (2015): Fỉlozofické poradenstvo - kritika. Univerzita Palackého, Olomouc.

Irwin, T. (2007): The Development of Ethics A Historical and Critical Study (Volume I: From Socrates to the Reformation). Oxford University Press, New York.

Lipman, M. (1993): Thinking Children and Education. Kendall Hunt Publishing Company, Iowa.

Lahav, R. (2014): „Interview with Viktoria Chernenko. Developing the Competencies of the Mind." In Welcome to the philopractice agora! The electronic meeting-place of philosophical practitioners from around the world [online] [cit. 13. 1. 2020]. Dostupné z: https://philopractice.org/web/viktoria-chernenko.

Louw, D. (2013): „Defining philosophical counselling: An Overview.“ South African Journal of Philosophy 32 (1): 60-70. 
Mareš, L. (2019): „Practical Role of Philosophy in Sport: Case of Philosophical Consultation." Physical Culture and Sport. Studies and Research (83): 16-25.

Nakonečný, M. (1995): Lexikon psychologie. Vodnář, Praha.

Nakonečný, M. (2015): Obecná psychologie. Triton, Praha.

Novák, L. \& Dvořák, P. (2007): Úvod do logiky aristotelské tradice. Jihočeská univerzita, České Budějovice.

NPCA (2014): „Practice Areas/Boundaries.“ In National Philosophical Counseling Association [Online]. (C) 2014 [cit. 31. 1. 2020]. Dostupné z: https://npcassoc.org/practice-areas-boundaries/

Pelcová, N. (2020): „Předmět: Dějiny filosofie výchovy.“ In Pedagogická fakulta, Univerzita Karlova. PROGRAM Filozofie výchovy a vzdělávání. [Online] Sylabus předmětu, Praha, PedF UK, (C) 2020 [cit. 4. 4. 2020]. Dostupné z: https://pedf.cuni.cz/ PEDF-2002.html.

Peregrin, J. (2010): „Filosofické poradenství, vzkvétající živnost.“ Filosofie dnes 2 (1): 55-57.

Platón (2005): Euthyfrón, Obrana Sókrata, Kritón. Přel. F. Novotný. OIKOYMENH, Praha.

Platón (2003): Kleitofón, Ústava, Timaios, Kritias. Přel. F. Novotný. OIKOYMENH, Praha.

Sharp, M. A. (2000): The Doll Hospital. ACER Press; český překlad (P. Bauman) Nemocnice pro panenky, TF JU, Centrum filozofie pro děti, České Budějovice, 2010.

Sharp, M. A. (2005): Jesse and Nakeesha. Les Presses de l'Université Laval, Québec; český překlad (M. Jedličková) Saša a Markétka, TF JU, Centrum filozofie pro děti, České Budějovice, 2011.

Šulavík, J. (2001): „Problém vztahu filozofie a psychoterapie.“ Filosofický časopis 49 (4): 585-601. 
Šulavíková, B. (2011): „Philosophical dialogue as a space for seeking

a good life, identity and critical thinking." Human Affairs 21 (2): 157-162.

\begin{abstract}

\section{Philosophical Practice In the Czech Republic}

The concept of philosophy has had several forms and meanings throughout the history. Besides the traditional theoretical focus, we may also encounter the approach that highlights a practical impact of philosophizing on one's life. This text introduces the concept of philosophical practice and reflects its current situation in the Czech Republic. Authors characterize philosophical practice as a discipline of philosophy and present its possible division into subsections. They also present its historical roots, which can be found in ancient Greece. Moreover, authors introduce available sources dealing with the philosophical practice and describe how this discipline is actually practiced in the Czech Republic. Detailed attention is given to three of its sections, namely philosophy for children $(\mathrm{P} 4 \mathrm{C})$, philosophical workshop, and philosophical consultation. Authors present theoretical background and also reflect their own methods in these sections. The text draws primarily from scholarly literature from abroad, particularly from the manuscripts and other sources produced by philosophical practitioners. The aim of this text is to introduce the concept of philosophical practice to the Czech reader and prepare the field for further academic discussion.
\end{abstract}

Keywords: philosophical practice, dialogue, philosophy for children, $\mathrm{P} 4 \mathrm{C}$, philosophical workshop, philosophical consultation

Mareš, L., Peltan, V. \& Havlová, E. (2020): „Filosofická praxe v České republice.“ Filosofie dnes 12 (2): 41-61. Dostupné z www.filosofiednes.ff.uhk.cz 